\title{
4 The rise of e-mobility as a trade-off between social and ecological benefits and distributional injustice
}

\author{
How the socio-technical regime and \\ externalisation prevent a profound \\ transformation of the mobility sector
}

Fabian Zimmer and Dörte Themann

\section{Introduction}

The global transport sector is responsible for more than $20 \%$ of the total energy-related $\mathrm{CO}_{2}$ emissions, and this figure is expected to increase in developed as well as in emerging economies due to growing traffic volume (IPCC 2014: 603). Therefore the Intergovernmental Panel on Climate Change (IPCC) demands transport emissions to 'be strongly decoupled from GDP growth', e.g. by using less carbon-intensive technologies like the electric drives (IPCC 2014: 603). Due to these developments, many states and cities decided to support the use of electric vehicles (EV) by a broad range of means. Car manufacturers are shifting their production and research towards electric vehicles in reaction to external pressure (e.g. emission limits, driving ban for cars with combustion engine) and in expectation of increasing demand. ${ }^{1}$ As a result of these decisions as well as of the progress in battery technology, the market share of electric vehicles is steadily growing and is expected to reach $57 \%$ of all passenger vehicle sales and over $30 \%$ of the global fleet until 2040 (BNEF 2019: 1).

As the demand for electric vehicles (especially batteries) rises, so does the demand for resources (namely for cobalt, lithium, nickel and rare earth elements) (Öko-Institut 2019; Köllner 2018). The mining of these elements (e.g. in the Democratic Republic of Congo or Chile) often leads to adverse environmental, social and human rights effects (Ali 2014; AI 2017, 2019). Despite extensive evidence on these problems, companies at the upper end of the supply chain (for example car manufacturers, battery producers) and their countries of origin take insufficient actions to ensure compliance with human rights and environmental protection standards (CNN 2018; AI 2017). 
These processes, which aim to improve the quality of life and the technological progress of developed countries at the expense of emerging and developing countries can be regarded as manifestations of the 'Externalisation Society' (Lessenich 2016) or the 'Imperial Mode of Living' (Brand \& Wissen 2017). While developed countries benefit from the rise of e-mobility, the resource-producing countries have to bear the social and ecological burdens.

This chapter shows that socio-technical dynamics towards technology transition as explained by Geels (2002; Geels \& Schot 2007) as well as the process of externalisation are two complementary concepts to explain the shift towards e-mobility in the automobile sector. Based on an extensive literature review the article analyses the drivers for the unjust distribution of benefits and drawbacks and especially the reasons for insufficient political and corporate action to tackle these challenges.

This approach is therefore different to and more profound than previous works of the social and ecological effects of electric mobility: not only the drawbacks are listed and explained by the operating mode of the economic system. However, the importance of the socio-technical regime is highlighted and its inhibiting effect on serious changes, favouring incremental innovation in the mobility sector, while wilfully ignoring the consequent adverse social and environmental effects.

\section{Theoretical background - externalisation and socio-technical dynamics}

For many people around the world, the electrification of mobility causes exploitation of labour-power. In addition, it causes the exposure to environmental and ecological risks, marginalisation in terms of social and health conditions and ultimately the destruction of ecosystems.

Prominent theoretical analyses of those dynamics are presented under the headings of 'Externalisation Society' by Lessenich (2016) and 'Imperial Mode of Living' by Brand and Wissen (2017), these will be explained in the first part of this section. The problems analysed by both concepts are very detailed and are based on several kinds of policy sectors and different aspects of everyday practices.

Besides, socio-technical dynamics play a significant role in the genesis of technology. For this reason, the second part presents a brief overview of what Geels has termed the multi-level-perspective of technology transitions.

\section{Externalisation society and imperial mode of living}

The analyses of Lessenich and Brand and Wissen shows why electric vehicles are not the silver bullet in mitigating climate change. The habitus of 'externalisation' plays a major role in this regard.

Economic theory describes external effects, also referred to as externalisation, as the phenomenon of transferring costs or socio-ecological adverse effects, that result as consequences of an economic action or decision, to the 'outside'. As a 
result, affected people or societies do not share the benefits of these decisions but have to bear their social and ecological consequences without getting compensated. With the economic term of external effects, Lessenich offers a sharp sociological analysis of Global North's present state of political, economic and societal acting. He traces the path of externalisation through an analysis of several areas of general life such as travelling, mobility, markets, etc. and uncovers the deep-rooted structures and mechanisms that manifest inequality and dependencies on a global scale (Lessenich 2016: 17). For Lessenich, there is not just one main driver for externalisation or one social actor like powerful economic or political elites. Instead, he describes the source of the externalisation society as a silent agreement and wilful participation of the majority of the population of 'Western' countries. Those Western societies can only stabilise and reproduce themselves on the basis of externalising costs and adverse effects (ibid.: 25).

The origin of externalisation can be found in history and now permeates all parts of society as purported by Lessenich. Brand and Wissen (2017) and their theory of 'Imperial Mode of Living' provides a similar analysis, however, with a stronger focus on how nature and labour become exploited (ibid.: 12), as a result of current capitalistic production and consumptions chains. According to the 'imperial mode of living', the conditions of the westernised way of life that includes a particular way of production can be described as 'imperial'. Imperial means disproportionate and unlimited access of an actor group on the 'outside' of their societal borders. The outside means especially resources in terms of either natural resources for production or human resources (especially labour) as well as the access to natural sinks. In other words, to externalise environmental risks and bads. $^{2}$ In this mode, normality is created by masking the destruction (ibid.: 13).

Despite their comprehensive analysis on how externalisation is deep-rooted in everyday life and societal structures, an aspect, which is mainly excluded in the approaches of Lessenich and Brand \& Wissen are the socio-technical dynamics. For this reason, the MLP approach is used to add this dimension and to introduce a concept that could integrate the 'habitus of externalisation'.

\section{The multi-level perspective developed by Geels}

One macro-perspective understanding regarding the dynamics of sociotechnical transitions is offered by Geels (2002). He understands transitions as the result of an interplay of different dimensions on three analytical levels: 'niches (the locus of radical innovations), the socio-technical regimes (the locus of established practices and associated rules that enable and constrain incumbent actors in relation to existing systems), and the exogenous sociotechnical landscape' (Geels 2014: 23, see also Geels 2002). In this way, technologies develop within a multi-level system, that is influenced by minor drivers as well as by deep anchored paradigms and paths.

The level for stabilising the system is the regime level (meso-level). On this level, incremental innovations are produced. Stabilising factors of the regime are: 'technology, user practices and application domains (markets), the symbolic 
meaning of technology, infrastructure, industry structure, policy and technoscientific knowledge' (Geels 2002: 1262). The regime also includes existing power relations, the influence of institutions, the interest of strong actor groups and different access to resources. Because of that, the 'sociotechnical regime' is the dominant level, where extreme changes are prevented. In contrast, visions or radical and regime challenging innovations arise from niches (micro-level) (see Grießhammer \& Brohmann 2015).

On the macro level, the so-called landscape, higher-level processes and events are located. Similar to the niches on the micro-level, the landscape exerts pressure on the regime to change (ibid.: 17). But the landscape can also be constituted in a way that hinders innovation or radical change. Geels describes the external landscape as a layer where 'deep structural trends' (Geels 2002: 1260) are located. Wars and drastic events are part of the landscape, but also environmental problems, norms and values.

Increasing structuration of activities in local practices

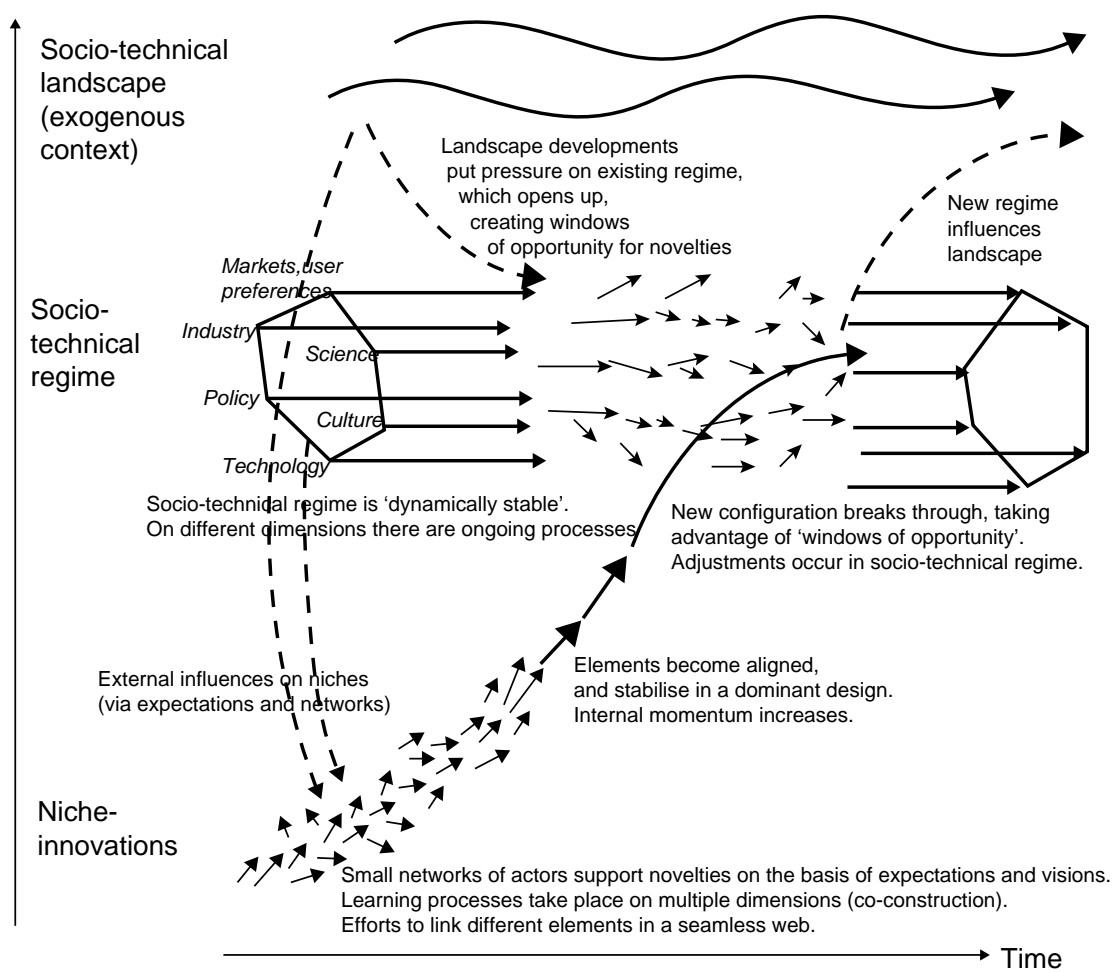

Figure 4.1 Levels which influence technology transitions (see Geels \& Schot 2007: 401). 
If one views the MLP and the externalisation approach side by side, it becomes apparent that they are not mutually exclusive but have the potential to complement each other. Paraphrasing the term of Jasanoff (2004), it could be that the dynamics of externalisation and the socio-technical dynamics are interdependent in a co-productive way, meaning co-producing strong technological regimes.

\section{Drivers for and externalities of electric vehicles}

The exploitation and production of resources for electric vehicles and the production chain for electric cars for the Global North fit perfectly to concepts of externalisation or imperial mode of living. This section first provides an overview of international cases where externalisation becomes observable. Second, the dynamics are outlined that stabilise the car regime and influence the technology genesis of the electrification of vehicles.

\section{Externalities of resource exploitation}

\section{Increasing demand for resources}

The economic profits are predominantly for the benefit of highly developed areas, whereas most of the essential resources are mined in African and South American countries. Thereby the demand for elements central for these technologies is expected to increase significantly mainly as components of (e-vehicle) batteries: the demand for cobalt, of which $60 \%$ is mined in the Democratic Republic of Congo, will strongly increase and possibly more than double until 2026 (Al Barazi 2018: 9). A similar development is predicted for lithium, leading to demand two or three times higher than in 2016 by 2026 (Schmidt 2017: 12). Almost half to the lithium originates from Chile, Argentina and Brazil and about 40\% from Australia (Schmidt 2017: 43). Other crucial components are rare earth elements, for which China is by far the biggest producer (more than 90\%) (USGS 2019: 133).

\section{Environmental hazards}

The mining process for rare earth elements, for example, requires vast amounts of water (which leads to lower groundwater levels and desertification) and chemicals. The often chemically and radioactively contaminated residues are stored in insufficiently protected landfills and artificial lakes. Consequently, the toxic residues can be accidentally released to the environment and then pollute land and water (Müller 2018: 28).

The production of lithium located in salt lakes, which is the case in South America, requires significant amounts of water. The massive water consumption states a severe environmental threat to these arid areas because of sinking groundwater levels and drying out of rivers (Öko-Institut 2017: 47f.). 
Social and human rights risks

Mining for electric vehicle components gives also rise to a number of social and human rights risks. The contamination of soil and water in the course of rare earth elements mining damages agricultural production of nearby farms and causes severe health problems (Müller 2018: 29). In Argentina, indigenous groups are not adequately informed about the impacts of lithium mining and are not involved in the planning processes for planned mining sites (AI 2019).

Cobalt mining in the Democratic Republic of Congo is especially problematic: particularly in artisanal mines workers lack adequate safety equipment or legal protection. Furthermore, even young children work in many of these mines. One further problem is that about $20 \%$ of the cobalt originates from this artisanal mining sector without proper regulations or supervision (AI 2017: 4).

\section{Insufficient monitoring and legislation}

Although those problems are widely known and recognised, the supply chains are often not transparent and the sources of the resources unknown. In particular, this is the case for cobalt mining in Congo where a significant part of the cobalt originates in artisanal mining, which is later mixed with cobalt from regular mines. Therefore, human rights groups accuse mining companies, suppliers and car manufacturers of inadequate measures to ensure transparency and safe working conditions (AI 2019).

In response to these accusations, several private sector initiatives were founded to enhance the transparency of the supply chain and eliminate the use of cobalt from untrustworthy sources. ${ }^{3}$ Additionally, international organisations provide frameworks for responsible mining, which can be adapted by companies. Nevertheless, only a minority of the companies producing and using batteries for electric vehicles use the OECD guidance as standards (AI 2017: 7). Also, the planned measures of the initiatives keep vague and comprehensive tracking of the origins is difficult as long as cobalt from artisanal mining is used and many intermediaries are involved between the mining and battery production (Washington Post 2016). A factor favouring weak monitoring is the lack of legal frameworks in car-producing countries to enforce such regulations. Although strict resource legislation already exists, for example, in the USA for conflict minerals (Dodd-Frank Act, Section 1502) and comes into force in the EU in 2021 (European Commission 2017), both do not include cobalt.

\section{Drivers for the electric automobile regime}

The main drivers of the transition of the mobility sector towards electric cars are climate change mitigation, the improvement of air quality as well as maintain or gain competitive advantages.

A major argument for transformation towards electric cars is their potential to lower GHG-emissions. This is supported by a broad range of influential actors, 
for example by scientific institutions as the IPCC (2014) or the European Environmental Agency (2018), governmental organisations as the European Commission (2019) and the German transport ministry (BMVI 2018) or also companies like the world's leading car-manufacturer Volkswagen (VW 2019b).

While the reduction of global warming can be seen as a global goal, ${ }^{4}$ the other drivers benefit only the countries where electric cars are used, which are mainly in Europe and China (WEF 2019a). Another benefit goes to the companies producing electric cars and batteries, which are primarily located in Europe, North America and Asia (Statista 2019a, 2019b). In some mostly Western countries, the automotive industry plays a major role in the domestic industry, employing hundreds of thousand people directly and indirectly and generating significant tax revenues. ${ }^{5}$ Accordingly, to gain competitive advantages can be regarded as one of the strongest motives for fostering electric vehicles (Altenburg 2014: 9ff.). Studies predict that in general ' $[\mathrm{t}]$ he transition from petroleum-based energy to renewably sourced energy will strengthen Europe's economy' (Harrison 2018: 4).

Due to the tax revenues ${ }^{6}$ and jobs depending on the car industry, there is a strong political interest to protect this sector. Therefore, the goal is to ensure a car-centric transport sector and maintain the leading role of the current manufacturers. Also, unions support this agenda to safeguard the jobs of the workers (Canzler \& Knie 2018: 11f.). It is anticipated that electric mobility and European battery cell production can significantly contribute to growth, employment and competitiveness of the industry of the EU (BMWi 2019).

Alongside economic and political reasons for choosing the electrification of road vehicles, solutions not challenging the car sector, in general, are also favoured due to the decades-long predominance of the automobile regime. Since becoming the predominant mode of transport in the first half of the 20th century it was considerably promoted by political decisions. These led to a higher attractivity of the car, to more users (Canzler \& Knie 2018: 31f.) and further consolidated and expanded its dominance (Cowan \& Hultén 1994). Today most of the (urban) infrastructure is optimised for road traffic (e.g. streets, parking lots, gas stations) and a shift to other transport modes is difficult due to the built cost-intensive car infrastructure. Although the status of the car as a symbol of independence and a good life is decreasing in the last years, the narrative is still existing and powerful (Canzler \& Knie 2018: 58f.). A transformation needs, therefore, not only to change the car-centric infrastructure (in which massive investments were and are made), but also mental path dependencies of the people (Fischedick \& Grunwald 2017: 26).

\section{Analysis: externalisation as a stabilising motive of the socio-technical regime}

In the following section, the transition in the automobile regime towards electric vehicles will be analysed with the MLP in combination with the theories of Lessenich and Brand and Wissen. 


\section{The landscape: wilful ignorance and climate change}

Based on the theory of externalisation society and the empirical evidence, it is reasonable to understand the externalisation of social and ecological risks in the course of transition towards electric vehicles as a consequence of in-depth structural trends that are inscribed in societal structures and everyday practices (Brand \& Wissen 2017: 48ff.). Externalisation is part of the external landscape as it describes an, in parts, unconscious discourse and mental model of society. Being part of the external landscape, it influences the socio-technical regime and technology transitions.

Including the 'habitus of externalisation', the landscape provides a stabilising effect towards the socio-technical regime of the automobile. Shocking events like the 'diesel-affair' or deep-rooted societal discourses like climate change confront the regime and pressure it to change towards a reduction of fossil fuel use. However, the deep-rooted mentality of externalisation produces a balancing moment regarding this pressuring effects and stabilises the regime in a way that radical changes from niches are not taken up. Demands from the civil society or scientific actors to also reflect socio-ecological problems of the entire value chain are not taken into account. Because of the habitus of externalisation in combination with a perceived urgency caused by current climate change discourses, incremental innovations inside the regime logic seem to be sufficient. The exclusive focus on climate change as the paramount problem cannot overcome the phenomena of social and ecological inequality. The current external landscape facilitates technological strategies that include wilful ignorance and sidetracking.

The discourse about climate change, in this interpretation, creates pressure to react fast, while the need for fast reactions in such dimensions tempts decision-makers and industry to look for answers only in the application of technology and not in the change of societal structures.

\section{The socio-technical regime: externalisation as stabilising mode of living}

An 'externalisation society' and the 'imperial mode of living' also fit into the socio-technical regime level. Brand and Wissen describe the imperial mode of living as a habitus or culture that influences decision-making processes and sections policies inside the regime and are part of user practices and markets.

One influencing factor on the regime level, which is rather disregarded in the analyses of Lessenich or Brand and Wissen is the role of techno-scientific knowledge. We observe a robust co-productive relation between science, industry and politics which mutually reinforce one another (Canzler \& Knie 2018: 55f.). Accordingly, research funds for the electrification of mobility reach billions of dollars, aiming to optimise the predominant regime instead of changing it (BMBF 2019; BMWI 2019).

Tracing the technical genesis of the automobile reveals that current forms of mobility are not only part and outgrowth of the imperial mode of living (Brand \& 
Wissen 2017: 125ff.), but that vice versa the practice of externalisation also is influencing the technology genesis of the mobility industry today.

Additionally, the development of the automobile is also influenced by path dependencies and lock-ins, based on, for example, 'sunk costs' (lost investments in case of system change), 'scale effects' (cost benefits because of mass production), 'network effects' (high amount of users) (Fischedick \& Grunwald 2017: 26) and mental path dependencies. This further stabilises the prevailing automotive regime.

\section{The niches: why do efforts and discourses to overcome externalisation not succeed?}

Technical alternatives are not marketable ${ }^{7}$ and critical socio-ecological discourses are not strong enough to overcome the externalisation paradigm. The acuteness of climate change screens the regime level from radical niche activities, that would presumably need more time for meeting climate protection requirements. Instead, incremental innovation is sought.

While radical paths and system-questioning discourses from the niche level (for instance degrowth and sufficiency, car-free mobility, and so forth), become more intense, they are also not successful in overcoming the current regime. One reason is that the automobile is a manifest expression of the imperial mode of living (Brand \& Wissen 2017: 125ff.).

\section{Conclusions}

For a long time, the automobile with an internal combustion engine (ICE) and the interdependent development of analogous areas (e.g. petrochemical industry, specialised professions) dominated the mobility in most countries (Cowan \& Hultén 1996). Due to external pressure, the dominance of the ICE is decreasing today and will probably be replaced by the electric motor (BNEF 2019: 1). However as this analysis makes clear, the strong socio-technical regime of the automobile, which is stabilised by different factors like the need for climate protection, political and corporate interests, path dependencies, consumer preferences and overall the habitus of externalisation, prevents a profound change of the transport sector. Thus, only the drive technology is changing while the general auto-centric mobility system remains intact and the subsequent social and ecological externalities are, again, addressed insufficiently.

The further development of this transition is difficult to anticipate because mobility states a complex socio-technical system. Impacts of a path are often visible only at a later point (Fischedick \& Grunwald 2017: 12) and are full of 'unknown unknowns' (Eckhardt \& Rippe 2016). The probability is high that new path dependencies are created that will make it difficult again to overcome the socio-ecological problems (as resistance against such measures illustrates, e.g. the gilets jaunes movement in France). The fading dominance of the established producers and the intensifying competition among old and new 
players reduces the probability of a resource policy led by social and ecological considerations, instead low prices and reliable supply, are of tantamount importance.

The actual transition towards electric drives for a still auto-centric mobility, whereby societal structures and the socio-technical regimes remain unaffected, is also caused by a wilful ignorance that is intrinsic in the dynamics of externalisation.

Nevertheless, there are urban areas that already function as learning laboratories and try to show a new practice without the automobile. Also, scientists from different disciplines, as well as NGOs, broaden the discourse beyond the technological focus. However, the question remains, whether such voices will challenge the regime profoundly enough considering the stabilising forces in culture, industry, politics and legislation. ${ }^{8}$

\section{Notes}

1 E.g. Volkswagen as the world biggest car manufacturer announced to electrify 'the vehicle portfolio, with investment in this area alone amounting to more than $€ 30$ billion by 2023' (VW 2019a).

2 The term of environmental bads is quite common when referring to phenomena of environmental (in-)justice. In environmental justice theory it is used contrary to environmental goods or benefits.

3 Examples are the 'Responsible Cobalt Initiative' to reduce social and environmental risks (CCCMC 2016), the new regulations of the 'London Metal Exchange' to rule out child labour (CNN 2019) or the 'Global Battery Alliance' to ensure a sustainable battery value chain (WEF 2019b).

4 It has to be stated the GHG-reduction potentials of electric cars are still unclear (see for example Hill et al. 2019).

5 In Germany alone more than 800.000 people are directly or indirectly employed in this sector and the manufacturers generate revenues of more than $€ 420$ billion (VDA 2018).

6 In the case of VW the state of Lower Saxony is even shareholder of the company (11.8\%) (VW 2018).

7 See for example Turcheniuk et al. (2018).

8 E.g. in the German transport legislation priority is given to the needs of individual motorised transport (Bundesregierung 2001; Canzler \& Knie 2018: 37).

\section{References}

AI. (2017). Time to recharge: corporate action and inaction to tackle abuses in the cobalt supply chain. London, England: Amnesty International.

AI. (2019). Amnesty challenges industry leaders to clean up their batteries. Retrieved from www.amnesty.org/en/latest/news/2019/03/amnesty-challenges-industry-leaders-toclean-up-their-batteries [14.07.2019].

Al Barazi, S. (2018). Rohstoffrisikobewertung - Kobalt: DERA Rohstoffinformationen 36. Berlin, Germany: Deutsche Rohstoffagentur.

Ali, S. (2014). Social and environmental impact of the rare earth industries. Resources 3(1), 123-134.

Altenburg, T. (2014). From combustion engines to electric vehicles: a study of technological path creation and disruption in Germany. Bonn, Germany: Deutsches Institut für Entwicklungspolitik. 


\section{Fabian Zimmer \& Doerte Themann}

Bijker, W. E. (1995). Sociohistorical technology studies. In Sheila J., G. E. Markle, J. C. Petersen \& T. Pinch (Eds.): Handbook of science and technology studies (229-256). Thousand Oaks, CA: Sage Publ.

BMBF. (2019). Dachkonzept'Forschungsfabrik Batterie'. Retrieved from www.bmbf.de/ files/BMBF_Dachkonzept_Forschungsfabrik_Batterie_Handout_Jan2020.pdf [14.07.2019].

BMUB. (2016). German Resource Efficiency Programme II: programme for the sustainable use and conservation of natural resources. Berlin, Germany: BMUB.

BMVI. (2018): The future of mobility is electric. Retrieved from www.bmvi.de/SharedDocs/ EN/Dossier/Electric-Mobility-Sector/electric-mobility-sector.html [06.09.2019].

BMWi. (2019). Bekanntmachung des Interessensbekundungsverfahrens zur geplanten Förderung im Bereich der industriellen Fertigung für mobile und stationäre Energiespeicher (Batteriezellfertigung). Retrieved from www.bmwi.de/Redaktion/DE/ Downloads/B/bekanntmachung-zur-geplanten-foerderung-einer-batteriezellproduktion. pdf?_blob=publicationFile\&v $=3$ [14.07.2019].

BNEF. (2019). Electric vehicle outlook. Retrieved from https://about.bnef.com/electricvehicle-outlook/\#toc-download [14.07.2019].

Brand, U. \& Wissen, M. (2017). Imperiale Lebensweise: Zur Ausbeutung von Mensch und Natur im globalen Kapitalismus. Munich, Germany: Oekom verlag.

Bundesregierung (2001). Allgemeine Verwaltungsvorschrift zur Straßenverkehrs-Ordnung: Retrieved from www.verwaltungsvorschriften-im-internet.de/bsvwvbund_26012001_ S3236420014.htm [19.07.2019].

Canzler, W. \& Knie, A. (2018). Taumelnde Giganten: Gelingt der Autoindustrie die Neuerfindung?. Munich, Germany: Oekom verlag.

CCCMC. (2016). Responsible Cobalt Initiative (RCI). Retrieved from www.cccmc.org. cn/docs/2016-11/20161121141502674021.pdf [14.07.2019].

CNN. (2018). Carmakers and big tech struggle to keep batteries free from child labor. Retrieved from https://money.cnn.com/2018/05/01/technology/cobalt-congo-childlabor-car-smartphone-batteries/index.html [14.07.2019].

CNN. (2019). The world's biggest metal exchange is getting serious about child labor and conflict minerals. Retrieved from https://edition.cnn.com/2019/04/23/business/ london-metal-exchange-child-labor/index.html [14.07.2019].

Cowan, R. \& Hultén, S. (1996). Escaping lock-in: the case of the electric vehicle. Technological Forecasting and Social Change, 53(1), 61-79.

Dodd-Frank Wall Street Reform and Consumer Protection Act, Pub. L. No. 111-203, \929-Z, 124 Stat. 1376, 1871 (2010) (codified at 15 U.S.C. \ 780).

Eckhardt, A. \& Rippe, K. P. (2016). Risiko und Ungewissheit? Bei der Entsorgung hochradioaktiver Abfälle Zurich: Switzerland: vdf.

European Commission (2017). Conflict minerals: the regulation explained. Retrieved from http://ec.europa.eu/trade/policy/in-focus/conflict-minerals-regulation/regulationexplained/\#regulation-why [14.07.2019].

European Commission (2019). Clean transport, urban transport: electric vehicles. Retrieved from https://ec.europa.eu/transport/themes/urban/vehicles/road/electric_en [04.09.2019].

European Environmental Agency (2018). Electric vehicles: a smart choice for the environment. Retrieved from www.eea.europa.eu/articles/electric-vehicles-a-smart [04.09.2019].

Fischedick, M. \& Grundwald, A. (2017). Pfadabhängigkeiten in der Energiewende: Das Beispiel Mobilität. Munich, Germany: acatech. 
Geels, F. W. (2002). Technological transitions as evolutionary reconfiguration processes: a multi-level perspective and a case-study. Research Policy 31(8-9), 1257-1274.

Geels, F. W. (2014). Regime resistance against low-carbon transitions: introducing politics and power into the multi-level perspective. Theory, Culture \& Society 31(5), 21-40.

Geels, F.W. \& Schot, J.W. (2007). Typology of sociotechnical transition pathways. Research Policy, 36(3), 399-417.

Grießhammer, R. \& Brohmann, B. (2015). Wie Transformationen und gesellschaftliche Innovationen gelingen können: Transformationsstrategien und Models of Change für nachhaltigen gesellschaftlichen Wandel. Baden-Baden, Germany: Nomos.

Harrison, P. (2018). Fuelling Europe's future: how the transition from oil strengthens the economy. Brussels, Belgium: European Climate Foundation.

Hill, G., Heidrich, O., Creutzig, F. \& Blythe, P. (2019). The role of electric vehicles in near-term mitigation pathways and achieving the UK's carbon budget. Applied Energy 251, 1-8.

IPCC (2014). Climate Change 2014: Mitigation of climate change. Cambridge, England \& New York, NY: Cambridge University Press.

Jasanoff, S. (2004). States of knowledge. the co-production of science and the social order. London, England: Routledge (International library of sociology).

Köllner, C. (2018). Seltener Seltene Erden verwenden. Retrieved from www. springerprofessional.de/elektromotor/werkstoffe/seltener-seltene-erden-verwenden/ 16105028 [14.07.2019].

Lessenich, S. (2016). Neben uns die Sintflut: Die Externalisierungsgesellschaft und ihr Preis. Munich, Germany: Hanser Berlin.

Müller, A. (2018). Rohstoffe für die Energiewende: Menschenrechtliche und ökologische Verantwortung in einem Zukunftsmarkt. Aachen, Germany: Bischöfliches Hilfswerk MISEREOR.

Öko-Institut (2017). Strategien für die nachhaltige Rohstoffversorgung der Elektromobilität: Synthesepapier zum Rohstoffbedarf für Batterien und Brennstoffzellen. Berlin, Germany: Agora Verkehrswende.

Öko-Institut (2019). Gigafactories für Lithium-Ionen-Zellen: Rohstoffbedarfe für die globale Elektromobilität bis 2050. Retrieved from www.oeko.de/fileadmin/oekodoc/ Fab4Lib-Rohstoffe-Elektromobilitaet.pdf [14.07.2019].

Schmidt, M. (2017). Rohstoffrisikobewertung - Lithium: DERA Rohstoffinformationen 33. Berlin, Germany: Deutsche Rohstoffagentur.

Statista. (2019a). Prognose der Zellproduktion von Batterien für Elektroautos in ausgewählten Ländern weltweit im Zeitraum der Jahre 2016 bis 2021. Retrieved from https://de.statista. $\mathrm{com} /$ statistik/daten/studie/896546/umfrage/prognose-der-produktionskapazitaet-vonbatteriezellen-fuer-elektroautos-weltweit/ [14.07.2019].

Statista. (2019b). Anzahl der produzierten Elektroautos im Jahr 2016 nach ausgewählten Ländern. Retrieved from https://de.statista.com/statistik/daten/studie/168065/umfrage/ anzahl-der-produzierten-elektroautos-nach-laendern/ [14.07.2019].

Turcheniuk, K., Bondarev, D., Singhal, V. \& Yushin, G. (2018). Ten years left to redesign lithium-ion batteries. Nature, 559(7715), 467-470.

USGS. (2019). Mineral commodity summaries: rare earths. Retrieved from https://prdwret.s3-us-west-2.amazonaws.com/assets/palladium/production/atoms/files/mcs-2019raree.pdf [14.07.2019].

VDA. (2018). Zahlen und Daten. Retrieved from www.vda.de/de/services/zahlen-unddaten/zahlen-und-daten-uebersicht.html [14.07.2019]. 


\section{Fabian Zimmer \& Doerte Themann}

VW. (2018). Aktionärsstruktur. Retrieved from www.volkswagenag.com/de/InvestorRelations/ shares/shareholder-structure.html [14.07.2019].

VW. (2019a). Volkswagen plans 22 million electric vehicles in ten years. Retrieved from www.volkswagen-newsroom.com/en/press-releases/volkswagen-plans-22-millionelectric-vehicles-in-ten-years-4750 [14.07.2019].

VW. (2019b). 'Volkswagen accepts climate responsibility'. Retrieved from www. volkswagenag.com/en/news/stories/2018/12/volkswagen-accepts-climateresponsibility.html [06.09.2019].

Washington Post (2016). The cobalt pipeline. Tracing the path from deadly hand-dug mines in Congo to consumers' phones and laptops. Retrieved from www. washingtonpost.com/graphics/business/batteries/congo-cobalt-mining-for-lithium-ionbattery/??noredirect $=$ on [14.07.2019].

WEF. (2019a). These countries have the highest share of electric vehicles. Retrieved from www.weforum.org/agenda/2019/03/chart-of-the-day-half-of-new-cars-sold-in-norwayare-electric-or-hybrid/ [14.07.2019].

WEF. (2019b). Global Battery Alliance. Retrieved from www.weforum.org/globalbattery-alliance [14.07.2019]. 